Łukasz Barciński

Institute of English Studies,

University of Rzeszow, Rzeszow, Poland

\title{
The Intricacies \\ of the Postmodern Convention - Thomas Ruggles Pynchon in Polish Translation
}

\begin{abstract}
The article presents the prominent figure of the contemporary American writer, Thomas Ruggles Pynchon, a leading representative of the postmodern literary convention. The study contains a brief introduction of his works, with a special focus on the canonical novel for the postmodern convention i.e. Gravity's Rainbow. The study will also apply McHale's concept of 'ontological dominant,' which aptly describes the shift from epistemological issues to existential ones occurring from modernist to postmodernist literature. Subsequently, the article discusses the main aspects of Pynchon's literary works and e.g. the presumed mode of reading i.e. 'creative paranoia,' encyclopaedicity and the interpretatively inconclusive binarities. Then, two fragments from Gravity's Rainbow in Polish translation are analyzed in terms of the preservation of the source text sense productive potential according to Venuti's theory of 'foreignization.' Finally, the study offers conclusions related to the reasons as to why there seem to be considerable deficiencies in the Polish rendition of Pynchon's novels, attributing this fact to the lack of an equivalent literary convention in the Polish literary environment.
\end{abstract}

Key words: postmodernism, literary translation, American literature

\section{Thomas Pynchon and the postmodern convention}

In the late 1950 s of the $20^{\text {th }}$ century, a new convention emerged on the literary horizon, mainly in the United States. The convention, triggered by the post-war reality, did not formulate a specific literary program or a manifesto. However, it was possible to delineate the characteristics of the new phenomenon: focus on intertextuality, the prominence of the medium or the textual tissue of a literary work, ludicity, syncretism, parody, pastiche and metatexuality. The key facet of this type of literary production was the underlying presumption that everything had already been said or written, no novelty can be created and literature entered into an era of exhaustion 
during which it can only rework its previous accomplishments. Accordingly, the literary creation can only proceed by deconstructing the existing values (be it aesthetic, philosophical or literary ones), making them a part of perpetual play with the reader. This new literary convention, called 'postmodern,' still remains a revealing subject for Translation Studies owing to its experimental nature, even though, admittedly, it is no longer the focus of the bulk of critical attention.

One of the leading representatives of these new aesthetics, radically departing from realist or mimetic fiction, was the American writer, Thomas Ruggles Pynchon. It may be safely stated that, by virtue of his literary import, he "is to postmodernism as James Joyce is to modernism," aptly "representative" of the whole literary age (Nicol 189). The literary fame seems to be much deserved as Pynchon's works overflow with multiple references, enigmatic messages, unequivocal leads which have generated hosts of exegetes and numerous critical texts with ever-expanding 'Pyndustry' of hermeneutical reading companions promising to fathom the scripture of the postmodern prophet (Berressem 169-170).

\section{Gravity's Rainbow and other works}

Pynchon's oeuvre consists of one collection of short stories and eight novels, six of which have already been translated into Polish: The Crying of Lot 49 (49 idzie pod młotek),Gravity's Rainbow (Tęcza grawitacji), MasonEDixon (Mason i Dixon), Inherent Vice (Wada ukryta), Bleeding Edge (W sieci) and Vineland (Vineland). Arguably, Pynchon's most influential novel is Gravity's Rainbow, mainly since it constitutes a canonical work for the postmodern convention, epitomizing all the postmodern literary devices and marking a radical departure from earlier literary productions. Even though it is possible to extrapolate the protagonist (Tyrone Slothrop) and a plot (revolving around the involvement of V-2 rocket in WWII), the incredibly episodic textual world seems to constitute the epitome of literary fragmentation: over four hundred characters, esoteric and encyclopaedic allusions, endless digressions, oneiric and surrealistic narratives and uncontrolled shifts between narrators, which utilize a variety of literary techniques. The main storylines involve: Tyrone Slothrop, in search for his identity and "rocket-dowsing" erections; Roger Mexico, an English statistician, mourning the loss of his beloved Jessica Swanlake; Enzian, an African struggling to control a band of rocket technicians and Franz (a German engineer) and his daughter Ilse (Fowler 44-45). The multitude of vantage points and literary devices which exhaust the limits of fiction, gradually slide into the ontological, creating a polyhedral multiplicity of textual worlds.

\section{The ontological dominant}

The quest to determine one dominant tendency in Pynchon's novels seems to be only a forlorn hope. The American literary theorist, Brian McHale strives to explain the mechanism of Pynchon's fiction using the term 'ontological dominant,' which emphasizes the issues of existence and subjectivity. For McHale "an ontology is a description of a universe, not of the universe" (Postmodernist fiction 27), highlighting 
the indefinite article. He focuses on the radical change in Pynchon's writing that took place between The Crying of Lot 49 and Gravity's Rainbow. Even though Pynchon's oeuvre can be perceived as postmodern, for McHale The Crying of Lot 49 still, to a large extent, belongs to modernism as it "hesitates between the epistemological and the ontological lines of explanation, without finally resolving the hesitation" (Postmodernist fiction 24). Breakthrough is possible only thanks to Gravity's Rainbow where "anarchist miracle" happens:"another's world intrusion into this one" like "a kiss of cosmic pool balls" (Pynchon, The Crying of Lot... 88,92). The epistemological dead-end of modernism i.e. solipsism is finally transcended and replaced by the "unconstrained projection of worlds in plural," acknowledging the parallel existence of multiple worlds and their juxtaposition (McHale, Postmodernist fiction 24-25).

McHale defines the process of shifting from the epistemological to the ontological dominant (from modernist to postmodernist fiction) as a 'hemorrhage' (Postmodernist fiction 22). This term, or more precisely, ontological hemorrhage (ontorrhage), if applied to Translation Studies, might illustrate the transition to a different perception of the process of translation of experimental works from the point of view of postmodern or poststructuralist theory. From this perspective the source text (the original) does not have one pre-determined target text (the translation)but 'hemorrhages' into an infinite number of target texts based on the textual indeterminacies related to the ambiguities presumed by McHale's ontological dominant. In other words, the core meaning of the source text is not transported intact into a target text but might be recreated in the form of many virtually possible target texts and, arguably, the more a literary text becomes rooted in ontological ambiguity, the more possible translations it can have. Again, the referentiality to one fixed external world in modernist fiction seems to be replaced by the extreme loss of referentiality or to the vestigial referentiality as seen in postmodernist fiction, which creates textual gaps in the indeterminate world(s) of postmodern works e.g. Gravity's Rainbow, which have to be filled by the interpretative process of the reader/the translator (the hemorrhage of a literary work leads to the ontorrhage in the process of translation and the possibility of creating multiple translations).

The ambiguity of the existential condition experienced by Pynchon's characters, is shared by the readers themselves, as a consequence of the lack of any certainties of his narratives, being the primary effect of Pynchon's writing (Schaub 3-5). All depictions generate a multitude of possible worlds: "potential states of affairs, subjective realities, plans, expectations, dreams, fantasies" not revolving round a singular sphere of existence. Pynchon's characters are especially inclined to hallucinations or are paranoiacs "suffering systematized delusions and projecting hostile forces" (Siegel 50) striving to survive in between the clashes of "subjective realities, (...) multiply objective alternative worlds: 'lost' worlds, (...) parallel worlds, (...) passages between worlds (...), visitations form other worlds" and "cameo visitations from historical figures" (McHale, "Pynchon's Postmodernism" 104-105). Pynchon's novels are teeming with narratives which generate intertextual references, refusing to be subjected to one explanatory myth or a single grand narrative (Nicol 98) and displaying general skepticism towards Western master narratives e.g. the narrative of technological and scientific progress in Gravity's Rainbow. Pynchon focuses rather on "little narratives" and "small scale separatist cultural enclaves" (the anarchic Counterforce) and offers paradigms of the postmodern condition (the Zone, "a space of anarchic freedom, multiplicity and social improvisation" before the collapse of the Third 
Reich) (McHale, "Pynchon's Postmodernism" 98-99). Another ambiguity involves an element of play with the metaphorical and literal meaning of words, making it difficult to distinguish between the hierarchy of senses in a given linguistic item. McHale highlights the phenomenon he identifies as "worlds under erasure" i.e. the making and unmaking of the worlds depicted in the narrative by destabilizing devices of world "deconstructing, unnarrating or rescinding" ("Pynchon's Postmodernism" 108), full of "endless simulacra and drifting signifiers" (Kolbuszewska 86).

\section{Creative paranoia}

Gravity's Rainbow, organized around the novel's main metaphor, the V2 bomb, complicates the idea of simple correspondence between a character and the external world. The protagonist, Tyrone Slothrop, in his childhood, was conditioned by a scientist, Dr. Laszlo Jamf to identify the places where V2 rockets fall (exactly where Slothrop happened to have sex). The fact of programming makes it possible for readers to associate between Slothrop's sexuality and the phallic aspect of the rockets(sex/Eros and aggression/Thanatos), which again could be just random connotations. Gravity's Rainbow plays with the possibility that "everything is either deeply significant or entirely meaningless" (paranoia or anti-paranoia) (Nicol 9697). The novel is structured to highlight the focal point of paranoia: "the onset, the leading edge of the discovery that everything is connected" (Pynchon, Gravity's... 703). Pynchon does not offer the reader valuable clues step by step but "simply shadow[s] the labyrinthine and ultimately frustrated investigations" of the main character (e.g. Slothrop). What is worse, Slothrop eventually vanishes from the novel: "There ought to be a punchline, but there isn't. The plans went wrong. He is being broken down instead, and scattered" (Pynchon, Gravity's... 738). For Jameson such "decentered subjectivity" seems to be the characteristic of postmodern texts where characters have a tendency to become disintegrated into "a rubble of distinct and unrelated signifiers" (26). In the end, the reader has no other choice but to become inextricably intertwined in the endlessly frustrating activity of connecting various elements within the textual tissue. Consequently, the proper mode for reading Gravity's Rainbow seems to be "rhizomatic," exploring "a vast network of potential symmetries and correspondences," and although there is a distant promise of certain "coherence," it is impossible to find a conclusion in Pynchon's "oversignified" worlds. The rhizomatic reading facilitates making connections on "both a temporal and a spatial level," where any point of the narration "can potentially lead to any other" (Nicol 97-98).

Pynchon explores the notion of 'redundancy' in literature ('pleonastic fiction') through creative paranoia and anti-paranoia, experienced by both protagonists and readers of his novels:

Of course a wee-developed They-system is necessary - but it's only half a story. For every They there ought to be a We. In our case there is. Creative Paranoia means developing at least as through a We-system as a They-system. (...) [They-systems are] what They and Their hired psychiatrists call 'delusional systems' (Pynchon, Gravity's... 638).

Simultaneously, Pynchon suggests that it is possible to reach an opposite state of "anti-paranoia" in which "nothing is connected to anything" (Gravity's... 434), 
an overwhelming indifference in place of oversensitivity to signs. Pynchon's works, where endless patterns of signifiers lead only to more signifiers, each part of the textual matter can be equally meaningful (creative paranoia/each signifier contains meaning/zero redundancy) or totally meaningless (anti-paranoia/no signifier contains meaning/maximum redundancy). Pynchon's works seem to parody pleonastic fiction, at the same time offering two modes of reading, favoring the former one as anti-paranoia is "a condition not many of us can bear for long" (Gravity's... 434). Additionally, paranoia seems to be connected with the theme of Puritan ancestry, constituted by "a Puritan reflex of seeking other orders behind the visible" (Grav$i t y^{\prime}$ s... 188) and the theme of Preterites i.e. those passed over, not elected by God and consigned for damnation.

\section{Encyclopaedicity}

Pynchon's prose has been attached with many labels owing to its blatant information overload. One label might be 'hysterical realism' which refers to the elaborately absurd fiction, pursuing vitality by means of descriptive detail (Wood, "Human..."), the other - ludic syncretism to categorize Pynchon as a "homo ludens" of the postmodern era, who restlessly plays with cultural phenomena (Smith 3). The most appropriate label here is 'encyclopaedicity,' which allows exegetes to create patterns of interpretation in their paranoiac quest for sense. Mendelson perceives Gravity's Rainbow in a wider tradition of Western literature, enumerating its encyclopaedic aspects: specialized knowledge in some disciplines (in Gravity's Rainbow: ballistics, mathematics and chemistry), art envisioned outside the written fiction (e.g. film and opera), an extensive inclusion of literary styles from the most primitive such as proverb-lore (e.g. Proverbs for Paranoids)to the most esoterically sophisticated (Cabbalist narratives), gigantism (the angel over Lübeck), polyglottism (wordplay in more than seven languages such as German-Latin macaronic and Middle Dutch), philosophical references (e.g. to Max Weber), historical aspects of language (alphabetization in Kazakhstan) and grotesquerie (a list of perversions) (Mendelson 29-36). The inclusiveness of Gravity's Rainbow also seems to be manifested in its intertextuality as Pynchon's novels overflow with echoes of texts of dubious or untraceable origins (e.g. quotations from German romantic poetry). Generally speaking, encyclopaedicity in Pynchon's works plays an essential role as a defamiliarizing factor increasing the markedness of particular textual items.

\section{Other possible dominants}

More possible dominants can be found on the thematic level as "the nervous system of Pynchon's novel is (...) composed of webs of meaning interwoven into each other to create complex structures of suggestion, symbolism and coded value," where each sequence of a coded message is related to another chain of symbolism, which, in turn, links infinitely to others (for instance "paper" becomes associated with the negative codes of "white, language, bureaucracy and abstraction" and which, in turn, have their own interconnecting chains running through the whole Gravity's Rainbow) (Fowler 23-25). Binary oppositions in Pynchon's novels are not an end in 
themselves, but lead to an infinite web of signifiers. As a result, by establishing one binary opposition the full underlying patterns of signification automatically become activated and everything truly becomes 'connected.' Nevertheless, it has to be mentioned that any of the inexhaustible binarities are only of a tentative nature. Therefore, any excessive adherence to any of them might transpire to be a kind of brutalization of Pynchon's double-coded and multilayered message.

Other possible dominants within Gravity's Rainbow might take a more literary angle. The Bakhtinian term 'chronotope' refers to "spatial and temporal indicators (...) fused into one, carefully though-out, concrete whole", where space responds to "the movements of time, plot and history" (Bakhtin 84). Kolbuszewska defines Pynchon's chronotopic structures as "rhizomes in which all paths are paranoically connected but the center is 'always already' beyond reach"(217). In Gravity's Rainbow "the apocalyptic moment is reached" in a sphere of "a palimpsest of discourses" and "the indeterminate, incomplete and chaotic quest (...) best described as an impaired mandala or the serpent from Kekule's dream" (Kolbuszewska 139).

\section{Gravity's Rainbow in translation}

For the purpose of this article two symptomatic excerpts from Gravity's Rainbow will be analyzed to provide a representative sample of the shifts of meaning that occur in the Polish translation and to determine to what extent the intricacies of the mechanism of Pynchon's fiction has been recreated in the Polish version.

(Example 1) The following fragment depicts one of the protagonists, Teddy Bloat, living in the secret British agent, Geoffrey 'Pirate' Prentice's humble abode during WWII.

Bloat is one of the co-tenants of the place, a maisonette erected last century, not far from the Chelsea Embankment, by Corydon Throsp, an acquaintance of the Rossettis' who wore hair smocks and liked to cultivate pharmaceutical plants up on the roof (a tradition young Osbie Feel has lately revived), a few of them hardy enough to survive fogs and frosts, but most returning, as fragments of peculiar alkaloids, to rooftop earth, along with manure from a trio of prize Wessex Saddleback sows quartered there by Throsp's successor, and dead leaves off many decorative trees transplanted to the roof by later tenants, and the odd unstomachable meal thrown or vomited there by this or that sensitive epicurean -all got scumbled together, eventually, by the knives of the seasons, to an impasto, feet thick, of unbelievable black topsoil in which anything could grow, not the least being bananas (Pynchon, Gravity's... 5).

Bloat jest jednym ze współlokatorów tego przybytku, domu wzniesionego w ubiegłym stuleciu niedaleko Chelsea Embankment przez Corydona Throspa, znajomego Rossettich, który nosił włosiennice i z upodobaniem hodował rośliny lecznicze na dachu (tradycja wskrzeszona ostatnio przez młodego Osbiego Feela). Kilka z nich okazało dostateczną odporność, by przetrzymać mgły i przymrozki, większość jednak powróciła do ziemi jako cząstki osobliwych alkaloidów wraz z nawozem od tria cenionych macior rasy wessekska siodłata, ulokowanych tu przez bezpośredniego sukcesora Throspa, suchymi liśćmi z licznych drzew ozdobnych, zasadzonych na dachu przez późniejszych lokatorów oraz 
okazjonalnym niestrawnym posiłkiem, wyrzuconym lub zwymiotowanym przez tego lub owego wrażliwego epikurejczyka - całość utarta, koniec końców, przez mieszadła pór roku na ciasto niewiarygodnej czarnej gleby grubości stopy, w którym rośnie wszystko, nie najgorzej banany (Pynchon, Tęcza... 11).

In many aspects the translation seems to precisely recreate the nuances of meaning: 'hair smocks' become 'włosiennice' (a type of outfit worn to obtain atonement); the variety of pigs 'Wessex Saddleback sows' is precisely rendered as 'maciory rasy wessekska siodłata' and 'epicurean' is accurately recreated as 'epikurejczyk' in the meaning of a gourmet. However, some elements of the imagery lack the necessary precision: 'maisonette' (a two-floor type of residential property) is replaced with a hypernym 'przybytek.' However, the biggest shift in the fragment concerns the extended imagery related to painting: in the source text the soil in which bananas are grown is compared to the product of a painting technique, while in the target text the imagery is conventionalized and replaced with the image of cooking. The original 'scumbling' (in the target text replaced by simple 'ucieranie' i.e. mixing) is a glazing technique, in which a layer of broken color is added over another one so that the lower layers show through. The tools used in this procedure to apply the consecutive layers are called 'knives,' again translated only as 'mieszadła' i.e. mixers, stripping the target text off the depth of the painting imagery. Additionally, the source text 'impasto' is another painting technique, in which the paint is applied thickly on the canvas (the target text uses the cooking metaphor of 'ciasto' i.e. dough). The original image where various painting techniques are utilized to produce a mixture of many permeative elements is not recreated and replaced by the image of dough being mixed.

(Example 2) The second fragment plays an important role in the way Gravity's Rainbow explores the themes of Puritanism and Calvinism. Slothrop's quest for identity is accompanied by references to his Puritan ancestry: within the divine scheme of salvation, the Puritan doctrine of predestination states that God chooses the Elect who will be saved, while the Preterite will suffer eternal damnation. As Mackey clarifies, "the heart of Calvinism is the doctrine of double predestination. All men are either Elect, the handful chosen for salvation, or Preterite, passed over and tacitly consigned to damnation" (17).

The rest of us, not chosen for enlightenment, left on the outside of Earth, at the mercy of a Gravity we have only begun to learn how to detect and measure, must go on blundering (...), hoping that for each psi-synthetic taken from Earth's soul there is a molecule, secular, more or less ordinary and named, over here-kicking endlessly among the plastic trivia, finding in each Deeper Significance and trying to string them all together like terms of a power series hoping to zero in on the tremendous and secret Function whose name, like the permuted names of God, cannot be spoken... (...) but to bring them together, in their slick persistence and our preterition... to make sense out of, to find the meanest sharp sliver of truth in so much replication, so much waste... (Pynchon, Gravity's... 590).

Reszta nas, nieprzeznaczonych do oświecenia, pozostawionych na powierzchni Ziemi, zdanych na łaskę Grawitacji, którą dopiero uczymy się rozpoznawać i mierzyć, błądzić musi (...), w nadziei że dla każdego psi-syntetyku wydartego duszy Ziemi istnieje po tej stronie świecka molekuła, mniej więcej zwykła, nazwana - grzebiemy niestrudzenie 
wśród plastikowych śmieci, znajdując w każdym Głębszą Doniosłość, próbując uporządkować je wszystkie jak człony szeregu potęgowego w wysiłkach dotarcia do tej potężnej i tajemnej Funkcji, której nazwy, podobnie jak rekonstruowanych imion Boga, nie można wymówić...(...) zgrupować to wszystko, w ich schludnej trwałości i naszym stanie pominięcia... dostrzec $\mathrm{w}$ tym sens, odnaleźć najlichsze ziarenko prawdy w masowym powielaniu, w masowych odpadach...(Pynchon, Tęcza... 465).

The mathematical reference seems to be precisely recreated: 'terms of a power series' become 'człony szeregu potęgowego' and 'Function' - 'Funkcja.' However in case of 'zero in on,' the mathematical imagery is not retained as the translation focuses only on the denotative meaning ('wysiłki dotarcia' i.e. efforts to reach), ignoring the associative implications for zero/one binarity within Gravity's Rainbow. The mixture of religious and mathematical imagery also lacks precision as 'permuted names of God' become 'rekonstruowane imiona Boga,' which removes in the target text the mathematical metaphor, describing the divine by means of the term 'permutation'. The target text conventionalizes the imagery by applying only 'rekonstruowane' (i.e. reconstructed) which ignores the meaning of 'permutation' (rearrangement of all the members of a set in an order) and does not recreate the associative multiplicity of ways, in which God can be named. As a result, the reference to cabbala is not recreated as cabbalistic texts deal with the permutation of the Sacred Name (YHVH). Another reference to cabbala is also not preserved as 'the meanest sharp sliver of truth' is rendered as 'najlichsze ziarenko prawdy' i.e. a conventionalization in the form of the idiom: 'a grain of truth'. The source text uses the term sliver' denoting a piece of broken glass, creating the image of shattered or debunked truth. As a result, the reference to cabbala is lost as in this tradition the concept of broken or shattered vessels explains the imperfection of the world. Finally, the religious term 'preterition' is rendered precisely only from the denotative point of view: 'stan pominięcia' (a condition of being passed over), which describes the fate of the Preterite according to Puritan beliefs. However, in the target text this term becomes less marked and does not foreground the important religious connotation of the concept, downplaying one of the most prominent binary opposition in the novel (the Elect vs. the Preterite).

\section{Results of the analysis}

For the purpose of the analysis, it seems useful to apply the theoretical framework introduced by Lawrence Venuti, who discusses the translator's invisibility along with two types of translating strategies: foreignization and domestication. Venuti criticizes domesticating translation as it involves "an ethnocentric reduction of the foreign text to target-language cultural values" (The Translator's Invisibility... 19-20). Foreignization, in contrast, "entails choosing a foreign text and developing a translation method along lines which are excluded by dominant cultural values in the target language" (Venuti, "The American Tradition" 242). For Venuti the act of domesticating translation is violent and presupposes power relations, regarding the supremacy of ideology of the target culture over the source culture which becomes stripped of its identity, which is why he suggests "restrain[ing] the ethnocentric violence of translation" and imposing "an ethnodeviant pressure on the [target culture] 
values to register the linguistic and cultural differences of the foreign text, sending the reader abroad" (The Translator's Invisibility...305-306).

As can be inferred from the above examples of translation analysis, although many items are precisely rendered, some pivotal elements are ignored or almost totally domesticated in the translation process. The domestication is particularly seen in areas which are essential for the comprehension of Pynchon's fiction such as the Puritan background (e.g. the unforegrounded translation of 'Preterition'). The infinite production of sense which could be activated by the unique metaphorical imagery also suffers in Polish translation (e.g. the painting, cabbalistic or mathematical imagery). This process of conventionalization in the process of translation might be called (after Venuti) 'belletrisation' of translation practice: making unsubstantiated choices on the basis of "unreflective impressionistic" aesthetic judgments and "aggressive anti-intellectualism that discourages thinking about translation", failing to acknowledge the fact that translation is always an act of interpretation (Translation Changes... 247).

\section{Convention in translation}

One of the reasons for the apparent domestication of postmodern literature in translation might be the lack of a similar convention in the Polish literary environment, which could result from the fact that the postmodern literary convention was defined mainly in the U.S. in the 1950s and 1960s.Wijowski attempts to trace the postmodern influence in Poland in: Parnicki, Lem, Gombrowicz and Tryzna, admitting that it appears to be debatable whether they can be hailed as truly postmodern. Many literary figures of the 1980s and 1990s border on postmodernism, but are never fully identified with it: Kuczok, Gretkowska, Pilch and (in the late 90s) Masłowska, Witkowski and Dukaj. Finally, it seems problematic whether such a label could aptly describe the most prominent Polish novels of the last twenty years (Wijowski 225-229). In general, Polish critics are very skeptical about the functionality of the term 'postmodern' in the Polish environment. The vagueness of the denotation of this concept adds to the overall confusion of its application in the field of literary and translation studies. Seemingly, in the Polish reception, postmodernism often seems to be a synonym for a total lack of moral values, blind nihilism or a passing pseudo-intellectual trend formed in the conditions of a post-capitalist society, and, therefore, considered suspicious especially by conservative circles. As a result, the reception of postmodern experimentalism is frequently seen solely through the perspective of nihilistic all-inclusiveness (in accordance with the postmodern credo 'anything goes'), ignoring other possible aspects of this concept, if applied to literary practice. Pynchon's works, the canon of postmodern literature (Hägg 262), cannot be reduced to mere experimental non-selectiveness, an observation corroborated by the numerous dominants discernible in his novels. Eventually, Pynchon's deeply humanistic message for humanity becomes distorted in the process of reception into "a failed experiment of worthless jabber induced by 'a narcotic trance'"1 (a review in Polityka quoted in Księżyk 2010). The failure to perceive a different mode of reading, resulting from the

\footnotetext{
1 Author's translation.
} 
realistic/modernist reading of a postmodern text (or possibly from the colossal difference between these within the generally perceived literary aesthetics), which, in turn, might stem from the lack of a postmodern canon in Poland (the lack of parallel aesthetics), seems to lead to the domestication of the translation product.

In conclusion, it may be stated that Pynchon's postmodern works pose an immense challenge to their translation. Postmodern literature, rooted in the linguistic medium, might still offer virtually insurmountable obstacles for translation such as the incompatibility of linguistic codes of the source and target language, even if the totality of multifarious aspects of sense production within the specificity of postmodern literature with its defamiliarizing momentum becomes properly acknowledged. Hopefully, through the bold application of creative strategies of foreignization, it might be possible to transplant the postmodern convention which grew on American soil onto the Polish linguistic ground.

\section{References:}

Bakhtin, Mikhail M. The Dialogic Imagination: Four Essays. Austin: University of Texas Press, 1992.

Berressem, Hanjo. "How to read Pynchon." [in:] Dalsgaard, Inger H., Herman, Luc, McHale, Brian (eds.). The Cambridge Companion to Thomas Pynchon. Cambridge: Cambridge University Press, 2012: 168-177, https:/ / doi.org/10.1017/CCOL9780521769747.016.

Fowler, Douglas. A Reader's Guide to Gravity's Rainbow. Ann Arbour: Ardis, 1980.

Hägg, Samuli. Narratologies of Gravity's Rainbow. Joensuun: Joensuunyliopisto, 2005.

Jameson, Fredric. Postmodernism, or the Cultural Logic of Late Capitalism. London and New York: Verso, 1991.

Kolbuszewska, Zofia. The poetics of chronotope in the novels by Thomas Pynchon. Lublin: The Learned Society of the Catholic University of Lublin, 2000.

Księżyk, Rafał. „Thomas Pynchon. Tęcza nad Polską.” Web. March 10, 2014. http:/ /niniwa22. cba.pl/thomas_pynchon.htm.

Mackey, Louis. “Paranoia, Pynchon, and Preterition.” Substance. Vol. 10, 1981: 16-30, https:// doi.org/10.2307/3684395.

McHale, Brian. Postmodernist fiction. London and New York: Routledge, 2004.

McHale, Brian. "Pynchon's Postmodernism." [in:] Dalsgaard, Inger H., Herman, Luc, and McHale, Brian (eds.). The Cambridge Companion to Thomas Pynchon, Cambridge: Cambridge University Press, 2012: 97-111, https:/ / doi.org/10.1017/CCOL9780521769747.010.

Mendelson, Edward. “Gravity's encyclopaedia."[in:] Bloom, Harald (ed.). Thomas Pynchon's Gravity's Rainbow. Philadelphia: Chelsea House Publishers, 1986: 29-52.

Nicol, Bran. The Cambridge Introduction to Postmodern Fiction. Cambridge: Cambridge University Press, 2009, https:// doi.org/10.1017/CBO9780511816949.

Pynchon, Thomas. The Crying of Lot 49. New York: Bantam, 1972.

Pynchon, Thomas. Gravity's Rainbow. New York: Viking Press, 1973.

Pynchon, Thomas. Tęcza grawitacji. Transl. Robert Sudół, Warszawa: Prószyński i S-ka, 2001.

Schaub, Thomas H. Pynchon: The Voice of Ambiguity. Chicago: University of Illinois Press, 1981.

Siegel, Mark R. "Creative Paranoia: Understanding the System of Gravity's Rainbow." Critique. Vol. 18, No. 3, 1977: 39-54.

Smith, Evans L. Thomas Pynchon and the Postmodern Mythology of the Underworld. New York: Peter Lang, 2012, http:/ / dx.doi.org/10.3726/978-1-4539-0951-5.

Venuti, Lawrence. The Translator's Invisibility: A History of Translation. London and New York: Routledge, 1995. 
Venuti, Lawrence. “The American Tradition.” Baker, Mona (ed.). The Routledge Encyclopaedia of Translation Studies. London and New York: Routledge, 1997: 305-315.

Venuti, Lawrence. Translation Changes Everything. Theory and Practice. London: Routledge, 2012.

Wijowski, Robert. Postmodernizm. Wartości powieści postmodernistycznej. Warszawa: Warszawska Firma Wydawnicza, 2012.

Wood, James. “Human, All Too Inhuman.” The New Republic Online. July 24, 2000. Web. June 12, 2014. http://www.powells.com/review/2001_08_30.html. 